\title{
Cardioprotective effects of the estrogen receptors modulators in the conditions of experimental acute myocardial infarction
}

\author{
S. V. Pavlov, K. V. Levchenko, S. V. Gorbachova \\ Zaporizhzhia State Medical University, Ukraine
}

According to modern ideas, in myocardial infarction a cascade of pathobiochemical reactions is triggered directly in the ischemic focus, leading to a disturbance in the metabolism of cardiomyocytes, the launch of "parasitral" energy-producing reactions, the development of mitochondrial dysfunction, the complete blockade of the macroergic compounds synthesis, and as a result, cells death. In this regard, in the acute period of myocardial infarction it is pathogenetically justified to use drugs that can affect cardiomyocytes metabolism and restore the course of bioenergetic reactions in the cell.

Aim of study - to evaluate the SERM cardioprotective effects in the conditions of acute myocardial infarction modelling with the use of the ST2 marker.

Materials and methods. The experimental part of the work was performed on 120 mature rats - males weighing 190-230 grams. Small-focal acute myocardial infarction was modelled by the administration of coronary artery spasm induced agents - pituitrin and $\beta 1,2,3$ isoprenaline adrenomimetic for 3 days. The investigated drugs tamoxifen citrate $(0.1 \mathrm{mg} / \mathrm{kg}$ ) (reg. № EF3300), toremifene (0.1 mg/kg) (reg. № 1705834), and also comparators - tiotriazoline (50 mg/kg) (UA/2931/01/02) and capicor (6 mg/kg) (reg. № 11114) were injected intraperitoneally 20 minutes after the injection of isadrin for 3 days in the above stated doses. The myocardial infarction development was confirmed by electrocardiographic study, as well as the appearance of troponin I in blood plasma. The directivity and severity of pathobiochemical processes in the cardiac tissue, as well as the effect of the studied drugs on them, were studied through the enzyme-linked immunosorbent assay of nitrotirozine and homocysteine concentration in the heart homogenate and ST2 in blood plasma.

Results. Systematic administration of a coronary artery spasm induced agents to laboratory animals led to a gradual, progressive ischemic lesion of cardiomyocytes. Biological markers of myocardial infarction Troponin, ST2 I were registered on the $3^{\text {rd }}$ day after the administration of pituitrin and isadrin in the blood plasma of the control group. Using selective receptors modulators and reference preparations (thiotriazoline, capicor) in experimental therapy of rats with experimental myocardial infarction promoted the normalization of biochemical processes in cardiomyocytes. However, the effect of the studied drugs was unidirectional with various degree of intensity. All the drugs statistically significantly reduced oxidative stress marker products. The most marked effects were displayed by the selective estrogen receptors modulators toremifene and tamoxifen, which decreased in ST2 blood plasma level (by more than $46 \%$ ) providing realization of IL-33 cardioprotective properties. In addition, SERM can limit oxidative and nitrosyl stresses development, leading to a decrease in the concentration of homocysteine and nitrotirozine in the heart. Interaction of these effects of tamoxifen citrate in conditions of acute myocardial infarction modelling resulted in a marked cardioprotective effect, increasing the percentage of animals which survived to an average of $75 \%$.

Conclusions. The cardioprotective effects of selective estrogen receptor modulators identified by us are an experimental foundation for the relevance and viability of further research in this direction.

\section{Кардіопротективні ефекти модуляторів естрогенових рецепторів в умовах експериментального інфаркту міокарда}

\section{С. В. Павлов, К. В. Аевченко, С. В. Горбачова}

Відповідно до сучасних уявлень, при інфраркті міокарда безпосередньо в осередку ішемії запускається каскад патобіохімічних реакцій, що призводить до порушення метаболізму кардіоміоцитів, запуску «паразитарних» енергопродукуючих реакцій, розвитку мітохондріальної диссункції, повної блокади синтезу макроергів та, як наслідок, загибелі клітин. У зв'язку з цим актуальним є пошук нових високоефективних лікарських препаратів, що здатні впливати на метаболізм кардіоміоцитів і відновлювати біоенергетичні реакції у клітині в гострий період інфраркту міокарда, а також розробка нових методів лабораторного скринінгу ефективності проведеної терапії.

Мета роботи - оцінювання кардіопротективних ефектів селективних модуляторів естрогенових рецепторів в умовах моделювання гострого інфаркту міокарда з використанням маркера ST2.

Матеріали та методи. Експериментальна частина роботи виконана на 120 статевозрілих щурах-самцях масою 190-230 г. Дрібновогнищевий гострий інфаркт міокарда моделювали шляхом уведення протягом 3 діб коронароспазмуючого агента пітуітрину та $\beta 1,2,3$ адреноміметика ізопреналіну. Досліджувані препарати: тамоксифену цитрат $(0,1$ мг/кг, reg. № EF3300), тореміфен (0,1 мг/кг, reg. № 1705834), а також референт-препарати - тіотриазолін (50 мг/кг, UA/2931/01/02) та капікор (6 мг/кг, reg. № 11114) уводили внутрішньочеревинно через 20 хвилин після введення ізадрину протягом 3 днів. Наявність інфаркту міокарда підтверджували електрокардіографічним дослідженням, а також визначенням тропоніну I у плазмі крові. Спрямованість і вираженість патобіохімічних процесів у серцевій тканині та вплив на них досліджуваних препаратів вивчали за допомогою імуноферментного визначення концентрації в гомогенаті серця нітротирозину, гомоцистеїну «Hоmocysteine», у плазмі крові - ST2.

Результати. Систематичне введення лабораторним тваринам коронароспастичного агента призводило до поступового, прогресуючого ішемічного ураження кардіоміоцитів. У плазмі крові тварин контрольної групи зареєстровано збільшення біологічного маркера інфаркту міокарда - тропоніну I, ST2. У гомогенаті серця зафіксовано розвиток оксидативного стре-

Key words: hypoxia, cardiomyocytes, selective estrogen receptors modulator, cytoprotection, ST2.

\section{Zaporozhye} medical journal 2017; 19 (6), 731-736 DOI: 10.14739/2310-1210 2017.6.114689

E-mail: zsmu.smu@yandex.ua
КАючові слова: гіпоксія, кардіоміоцити, селективні модулятори рецепторів естрогенів, цитопротекція, ST2.

\section{Запорізький} медичний журнал. - 2017. T. 19, № 6(105). C. $731-736$ 
су, про що свідчило підвищення концентрації нітротирозину та гомоцистеїну. Експериментальна терапія селективними модуляторами естрогенових рецепторів і референс-препаратами (тіотриазолін, капікор) сприяла нормалізації біохімічних процесів у кардіоміоцитах. Дія досліджуваних препаратів односпрямована, однак різного ступеня вираженості. Всі препарати статистично вірогідно знижували маркерні продукти оксидативного стресу, а також концентрацію маркера ST2 в плазмі. Найбільш виражені ефекти продемонстрували селективні модулятори естрогенових рецепторів тореміфен і тамоксифен, які зменшували вміст у плазмі крові ST2 (більш ніж на 46 \%), забезпечуючи реалізацію кардіопротективних властивостей IL-33. Крім того, SERM здатні обмежувати розвиток оксидативного та нітрозильного стресів, призводячи до зниження концентрації в серці гомоцистеїну та нітротирозину. Взаємопотенціювання цих ефектів тамоксифену цитрату в умовах моделювання гострого інфаркту міокарда призводило до вираженого кардіопротективного ефректу, збільшуючи відсоток тварин, які вижили, в середньому до $75 \%$.

Висновки. Встановлені нами кардіопротективні ефекти селективних модуляторів естрогенових рецепторів $є$ експериментальним обґрунтуванням актуальності та перспективності дальших досліджень у цьому напрямі.

\section{Ключевые слова: \\ гипоксия, кардиомиоциты, \\ Кардиопротективные эффекты модуляторов эстрогеновых рецепторов в условиях экспериментального острого инфаркта миокарда} селективный модулятор рецепторов эстрогенов, цитопротекция, ST2.

\section{С. В. Павлов, К. В. Аевченко, С. В. Горбачова}

Согласно современным представлениям, при инфаркте миокарда непосредственно в очаге ишемии запускается каскад патобиохимических реакций, приводящий к нарушению метаболизма кардиомиоцитов, запуску «паразитарных» энергопродуцирующих реакций, развитию митохондриальной дисфункции, полной блокаде синтеза макроэргов и, как следствие, гибели клеток. В этой связи актуальным является поиск новых высокоэффрективных лекарственных препаратов, способных воздействовать на метаболизм кардиомиоцитов и восстанавливать течение биоэнергетических реакций в клетке в острый период инфаркта миокарда, а также разработка новых методов лабораторного скрининга эфффективности проводимой терапии.

Запорожский медицинский журнал. - 2017. T. 19, № 6(105). C. 731-736

Цель работы - оценка кардиопротективных эффректов селективных модуляторов эстрогеновых рецепторов в условиях моделирования острого инфаркта миокарда с использованием маркера ST2.

Материалы и методы. Экспериментальная часть работы выполнена на 120 половозрелых крысах-самцах массой 190-230 г. Мелкоочаговый острый инфраркт миокарда моделировали путем введения на протяжении 3 суток коронароспазмирующего агента питуитрина и $\beta 1,2$, Задреномиметика изопреналина. Исследуемые препараты: тамоксифена цитрат (0,1 мг/кг, reg. № EF3300), торемифен (0,1 мг/кг, reg. № 1705834), а также рефреренс-препараты тиотриазолин (50 мг/кг, UA/2931/01/02) и капикор (6 мг/кг, reg. № 11114) вводили внутрибрюшинно через 20 минут после введения изадрина на протяжении 3 дней. Наличие инфаркта миокарда подтверждали электрокардиографическим исследованием, а также определением тропонина I в плазме крови. Направленность и выраженность патобиохимических процессов в сердечной ткани и влияние на них исследуемых препаратов изучали по иммуноферментному определению концентрации в гомогенате сердца нитротирозина, гомоцистеина «Ноmocysteine», в плазме крови - ST2.

Результаты. Систематическое введение лабораторным животным коронароспастического агента приводило к постепенному, прогрессирующему ишемическому поражению кардиомиоцитов. В плазме крови животных контрольной группы зарегистрировано увеличение биологического маркера инфаркта миокарда тропонина I, ST2. В гомогенате сердца зафиксировано развитие оксидативного стресса, о чем свидетельствовало повышение концентрации нитротирозина и гомоцистеина. Экспериментальная терапия селективными модуляторами эстрогеновых рецепторов и референс-препаратами (тиотриазолин, капикор) способствовала нормализации биохимических процессов в кардиомиоцитах. Действие исследуемых препаратов было однонаправленным, однако разной степени выраженности. Все препараты статистически достоверно снижали маркерные продукты оксидативного стресса, а также концентрацию маркера ST2 в плазме. Наиболее выраженные эффекты продемонстрировали селективные модуляторы эстрогеновых рецепторов торемифен и тамоксифен, которые уменьшали содержание в плазме крови ST2 (более чем на 46 \%), обеспечивая реализацию кардиопротективных свойств IL-33. Кроме того, SERM способны ограничивать развитие оксидативного и нитрозильного стрессов, приводя к снижению концентрации в сердце гомоцистеина и нитротирозина. Взаимопотенциирование данных эффректов тамоксифена цитрата в условиях моделирования острого инфаркта миокарда приводило к выраженному кардиопротективному эффекту, увеличивая процент выживших животных в среднем до 75 \%.

Выводы. Установленные нами кардиопротективные эффректы селективных модуляторов эстрогеновых рецепторов являются экспериментальным обоснованием актуальности и перспективности дальнейших исследований в этом направлении.

According to modern ideas, in myocardial infarction a cascade of pathobiochemical reactions is triggered directly in the ischemic focus, leading to a disturbance in the metabolism of cardiomyocytes, the launch of "parasitral" energy-producing reactions, the development of mitochondrial dysfunction, the complete blockade of the macroergic compounds synthesis, and as a result, cells death. In this regard, in the acute period of myocardial infarction it is pathogenetically justified to use drugs that can affect cardiomyocytes metabolism and restore the course of bioenergetic reactions in the cell $[1,2]$.
As of today, there are many metabolototropic cardioprotectors, - antihypoxants, antioxidants, antianginal drugs among them. However, the effectiveness of these drugs is only proven in subacute and recovery periods of myocardial infarction, the drugs are used chaotically, without a treatment strategy from the position of evidence-based medicine. In addition, these drugs in mitochondrial dysfunction forming conditions are not able to regulate the good molecular-biochemical pathways of energy metabolism [1].

A promising trend of new cytoprotective drugs development used in hypoxic cells damage is searching for 
the compounds that could induce endogenous cytoprotective factors (HSP-protein; HIF-proteins, NO) [2-4]. It is known that these factors play a key role in the implementation of compensatory-adaptive reactions of cells and activation of endogenous mechanisms of cytoprotection in response to hypoxia: inhibition of ATP hydrolysis and increase of anaerobic ATP formation, minimization of energy consumption, NO-dependent and humoral dilation of coronary and peripheral vessels $[5,6]$. Experimental research of the past decade conducted in this area have found a number of factors that can induce expression of chaperones, beginning with preconditioning, heat-shock and magnetic field, and ending with some drugs (antioxidants, triterpene compounds, arimoclomol, adenosine, nitrates, valproic acid, estrogen, etc.) [6]. Among these, special attention should be paid to estrogens. Historically, the studies of estrogens were carried out concerning their impact on the secondary sexual characteristics in females, myometrium mitotic activity, ovarian follicular granulosa cell proliferation and others [7-9]. However, the detection of a large number of estrogen receptors in tissues that are not classical estrogen targets, both in female and male individuals, suggests that estrogens do not only regulate reproductive processes in the body $[6,8,9]$. The new concept of cardio protective influence of estrogens based drugs, that has been mainly developed abroad, is based on a huge clinical material which indicates the ability of estrogens to prevent or slow down the progression of coronary heart disease, hypertension, paroxysmal forms of cardiac arrhythmias, atherosclerosis - especially in women with estrogens deficiency [6,9-11].

All of the above-mentioned provide foundation for the further study of estrogens cardioprotective properties. However, their direct hormonal activity and ambiguous effects on the blood clotting system limit estrogen cardioprotective drugs inclusion into treatment. In this regard, an interesting trend is the use of the so-called selective estrogen receptor modulators (SERM) as estrogen receptor agonists.

The unique pharmacology of SERM can be explained by three interacting mechanisms: 1) the differential expression of estrogen receptors in specific target tissue; 2) the differential conformation of the estrogen receptor upon binding ligand; 3 ) the differential expression and binding of co-regulatory protein with estrogen receptors [6,9]. The relative levels of two isoforms of estrogen receptors (ERa and ER $\beta$ ) expression are believed to affect the cellular response to estrogens. SERM can function as full antagonists, acting through ER $\beta$ genes that contain relevant elements, but may play a role of partial agonists, acting through Era $[8,11]$.

Taking into account all the above-mentioned, it is important to study the SERM cytoprotective effects in the conditions of acute myocardial infarction modelling. In recent years, both experimental and clinical studies have shown that it is appropriate to use the detection of a cardiac biomarker ST2 (Growth Stimulation Expressed Gene 2) [12,13] for the purpose of new cardioprotective drugs effectiveness pharmacological evaluation. ST2 is a member of the interleukin-1 receptor family. In the heart, ST2 plays a biological role in the innate immune process, and also modulates the cardiac signalling pathway. An important feature of ST2 is the rapid, under ischemia, blockade of IL-33 cardioprotective effect, which contributes to the heart remodeling and fibrosis development [14]. With adequately selected cardioprotective therapy, the concentration of ST2 decreases rapidly, which explains the prospect of its use for cardioprotective properties of the drugs evaluation in the study [12-14].

Thus, the aim of our study was to evaluate the SERM cardioprotective effects in the conditions of acute myocardial infarction modelling with the use of the ST2 marker.

\section{Materials and Methods}

The experimental part of the work was performed on 120 mature rats - males weighing 190-230 grams. Experimental animals were obtained from the Institute of Pharmacology and Toxicology of the National Academy of Medical Sciences of Ukraine. Small-focal acute myocardial infarction was modelled by the introduction of coronary artery spasm induced agents - pituitrin (1 unit/kg subcutaneously) and $\beta 1,2,3$ isoprenaline adrenomimetic $(200 \mathrm{mg} / \mathrm{kg}$ intramuscularly) for 3 days [15]. The investigated drugs - tamoxifen citrate $(0.1 \mathrm{mg} / \mathrm{kg}$ ) (reg. № EF3300), toremifene $(0.1 \mathrm{mg} / \mathrm{kg})$ (reg. № 1705834), and also comparators - tiotriazoline (50 mg/kg) (UA/2931/01/02) and capicor $(6 \mathrm{mg} / \mathrm{kg})$ (reg. № 11114) were injected intraperitoneally 20 minutes after the injection of isadrin for 3 days in the above stated doses. The myocardial infarction development was confirmed by electrocardiographic study, as well as the appearance of troponin I by "Immulite troponin I Kit 100T" ("Siemens") in blood plasma. The directivity and severity of pathobiochemical processes in the cardiac tissue, as well as the effect of the studied drugs on them, were studied through the enzyme-linked immunosorbent assay of nitrotirozine ("Nitritrosin" (ELISA Kit "Hycult biotechnology bv")) and homocysteine ("Homocysteine" ("Axis-Shield Diagnostics")) concentration in the heart homogenate and ST2 ("The Pressage ST2 Assay" (Critical Diagnostics)) in blood plasma.

The normality of the distribution was assessed by Kolmogorov-Smirnov (D), Lilliefors and Shapiro-Wilk (W) criteria. When the distribution was not normal or when we analyzed ordinal variables, we used the Mann-Whitney $U$ test for two unrelated samples; for a larger number of samples, we used Kruskal-Wallis $\mathrm{H}$ test followed by the Games-Howell comparison. A comparison of groups on the basis of attributes was performed using $X^{2}$ criterion with an analysis of contingency tables. Data are presented as the arithmetic mean and standard error of the representation of the mean value. The relationship between the studied variables was determined using binary regression analysis. The results were processed using the statistical software packages SPSS 16, Microsoft Excel 2003, and STATISTICA for Windows 7.0 (StatSoft Inc.); for all types of analysis a significance level of less than 0,05 was considered as a significant difference [16].

\section{Results and discussion}

Systematic administration of a coronary artery spasm induced agents to laboratory animals led to a gradual, progressive ischemic lesion of cardiomyocytes. As it can be seen in the Table 1, an increase in the biological marker of myocardial infarction, Troponin I, which concentration averaged $1.77 \mathrm{mg} / \mathrm{ml}$, was registered on the $3^{\text {rd }}$ day in the control group blood plasma after pituitrin and isadrin administration. Simultaneously, myocardial ischemia characterizing electrocardiographic changes were recorded 
Table 1. The influence of the studied drugs on pathobiochemical changes in the blood plasma and homogenate of the rat heart with experimental myocardial infarction

\begin{tabular}{llll}
\hline $\begin{array}{l}\text { Groups of animals } \\
(\mathrm{n}=10)\end{array}$ & $\begin{array}{l}\text { Troponin I, } \\
\mathrm{mg} / \mathrm{ml}\end{array}$ & $\begin{array}{l}\mathrm{ST2}, \\
\mathrm{mg} / \mathrm{ml}\end{array}$ & \multicolumn{2}{l}{$\begin{array}{l}\text { Nitrotyrosine, Standard unit, } \\
\text { /g/protein }\end{array}$} \\
\hline Intact group $(\mathrm{n}=10)$ & $0.25 \pm 0.02$ & $11.4 \pm 1.59$ & $0.14 \pm 0.03$ \\
Control group (myocardial infarction) $(\mathrm{n}=10)$ & $1.77 \pm 0.34^{*}$ & $47.2 \pm 6.47^{*}$ & $1.3 \pm 0.27^{*}$ \\
\hline
\end{tabular}

*: $p \leq 0.05$ in relation to the intact group of animals.

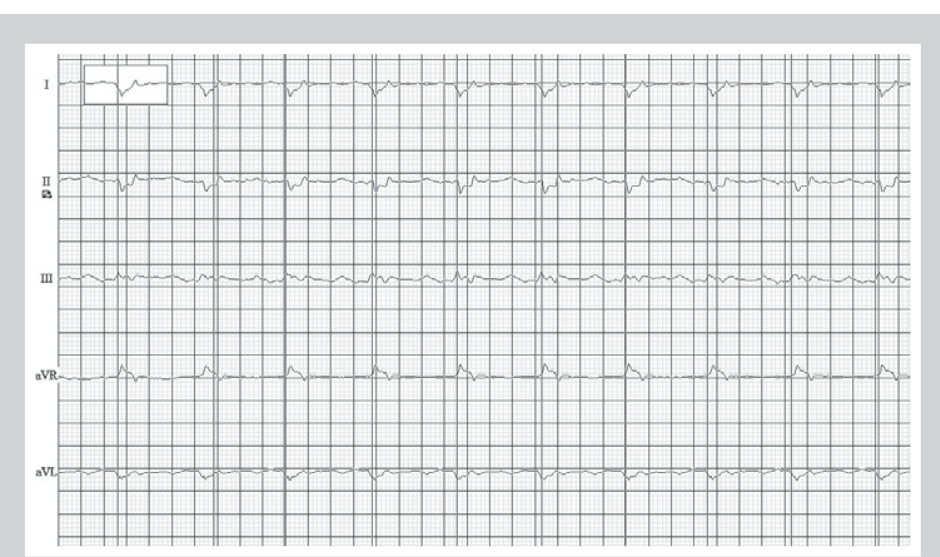

Fig. 1. Electrocardiogram of a rat with Q-myocardial infarction. of irreversible processes leading to the death of cardiomyocytes. Thus, the development of nitrative stress leads, through peroxynitrite hyperproduction, to the irreversible inhibition of mitochondrial respiration, directly interacting with the iron of key enzymes active centres, and also nitrosating the S-, N-, O-elements of thiol, phenol, hydroxyl and amino groups of the protein part of these enzymes; and in a stronger manifestation of nitrative stress, it irreversibly oxidizes them. In conditions of ischemic damage to heart tissue, the antioxidant balance shifts toward the prooxidant $[17,18]$. Accumulation of proteins oxidative degradation marker products occurs, especially Ntz, leading to the disruption in the functioning of proteins, especially the respiratory chain, and as a result, the death of the whole cell. Simultaneously, due to nucleic acids damage, oxidative stress leads to the inhibition of the genes expression responsible for the synthesis of endogenous cytoprotective factors (HSP-, HIF proteins), as well as antioxidant protection enzymes - catalase, superoxide dismutase [19].

Using tamoxifen $(0.1 \mathrm{mg} / \mathrm{kg})$, toremifene $(0.1 \mathrm{mg} / \mathrm{kg})$, thiotriazoline $(50 \mathrm{mg} / \mathrm{kg})$ and capicor $(6 \mathrm{mg} / \mathrm{kg})$ in experimental therapy of rats with experimental myocardial infarction promoted the normalization of biochemical processes in cardiomyocytes. Therefore, as it can be seen in the Table 2 , all the studied drugs reduced the concentration of nitrotyrozin in the heart homogenate, with a parallel decrease in the content of homocysteine. However, the effect of the drugs in the study was unidirectional, with various degree of intensity. All the drugs statistically significantly reduced oxidative stress marker products. Selective estrogen receptor modulator toremifene and compound with antioxidant properties tiotriazoline, as it is shown in the Table 2, were found to be the most active in their effect on the oxidative stress indicators, as they reduced the concentration of nitrotyrosine and homocysteine by an average of $60 \%$ and $70 \%$, respectively.

Interesting data were obtained by studying the character of ST2 concentration in the plasma of animals with myocardial infarction experimental therapy. So, it can be concluded from the Table 3, that the concentration of ST2 was comparable to the effectiveness of the drugs in their effect on the content of oxidative stress markers, although tiotriazolin showed slightly less activity. An important feature is that the obtained values of the ST2 concentration correlate with the number of survived animals in each experimental series. Therefore, the lower marker ST2 concentration, the larger number of experimental animals survived on the $4^{\text {th }}$ day of the modelled pathology. Based on the ST2 concentration, it is possible to construct a series of the studied drugs in descending order of their efficiency. This series has the range: toremifene - tamoxifen - capicor - thiotriazoline.

The prospective use of ST2 as a marker for monitoring the drugs effectiveness is explained by the integrative properties of this biomarker, reflecting changes in the three main links of myocardial infarction: hypoxia, inflammation, 
myocardial stress. As a "receptor-trap", sST2 binds to IL-33 and limits the realization of its cardioprotective effect. A number of studies have shown the relationship between the development of oxidative stress and hyperproduction of sST2 [12-14]. In addition, due to the limitftion of IL-33 biological effects, the cytoprotective activity of HSP and HIF proteins is also limited $[5,20]$. It is known that the induction of $\mathrm{HSP}$ and HIF proteins is the most conservative and universal system of cellular response to hypoxia. The ratio of the HSP level to the total protein level in a stress-affected cell is so large, that the amount of heat shock proteins in it reaches $15-20 \%$ of all dissolved cytoplasm proteins $[4,5,20]$. The last one with these proteins expression and synthesis induction in a cell under hypoxic conditions a number of researchers associate with the initiation of adaptive molecular-biochemical cell reactions in response to hypoxia. In this regard, the established ability of drugs to reduce the concentration of ST2 allows us to make an assumption about their ability to influence the content of HSP proteins, thereby activating the processes of rapid cell adaptation to hypoxic conditions. This statement is especially true for estrogen receptors modulators - tamoxifen and toremifene, the mechanism of cytoprotective action of which in conditions of ischemic genesis pathology is explained, among other things, by their ability to increase the content of HSP and HIF proteins in the cell, as we have shown in our earlier research.

To sum up, it has been determined in the course of experimental research that the studied drugs in the conditions of experimental myocardial infarction have complex cytoprotective effects aimed at oxidative and nitrosating stresses reduction reducing the concentration of ST2 marker. The cytoprotective effects of the above-mentioned drugs established by us were manifested in the increased number of survived animals on the $4^{\text {th }}$ day of myocardial infarction modelling. The analysis of the obtained data demonstrates that the leading mechanism of their cytoprotective effects is the ability to reduce the concentration of the ST2 marker. This property of the drugs is unidirectional, however it is realized in different ways. Thus, the antioxidant drug - tiotriazoline, is capable of binding the cytotoxic derivatives of the ROS to its $\mathrm{SH}$-groups, thereby reducing the concentration of nitrotyrosine and homocysteine. Thiotriazoline showed less pronounced effects in relation to ST2 marker concentration, which prevented it from fully implementing cardioprotective effects. Under the influence of tiotriazoline, the percentage of survived animals on the $4^{\text {th }}$ day of modelled pathology was only $50 \%$. Capicor proved to be more active, providing a decrease in ST2 by $33 \%$, and increasing the percentage of survived animals to $60 \%$. These effects of capicor, in our opinion, are explained by the combination of gamma-butyrobetaine dihydrate with meldonium dihydrate which, on the one hand, ensures the oxidative stress localization and on the other hand the normalization of biochemical processes in the mitochondria, reducing the lactic acidosis development. The most pronounced effects were displayed by the selective modulators of estrogen receptors - toremifene and tamoxifen. These drugs, in conditions of experimental myocardial infarction, due to the modulation of heart estrogen receptors (ER), caused conformational changes in the ER molecule and the release of HSP70 proteins from the complex with it and the input of the latter into the mitochondria. However, the decrease of ST2 in blood plasma (by more than $46 \%$ ) provides, in our
Table 2. The effect of the studied drugs on the content of oxidative and nitrosative stresses markers in cardiac homogenate of rats with experimental myocardial infarction

\begin{tabular}{lll}
\hline $\begin{array}{l}\text { Groups of animals } \\
(\mathrm{n}=10)\end{array}$ & $\begin{array}{l}\text { Nitrotyrosine, } \\
\text { Standard } \\
\text { unit/g/protein }\end{array}$ & $\begin{array}{l}\text { Homocysteine, } \\
\text { Mmol/l }\end{array}$ \\
\hline Intact group, $(\mathrm{n}=10)$ & $0.14 \pm 0.03$ & $0.4 \pm 0.11$ \\
Control group (myocardial infarction), $(\mathrm{n}=10)$ & $1.3 \pm 0.27$ & $3.7 \pm 0.88$ \\
Myocardial infarction + Tamoxifene citrate $(0.1 \mathrm{mg} / \mathrm{g}),(\mathrm{n}=10)$ & $0.65 \pm 0.14^{*}$ & $2.7 \pm 0.14^{*}$ \\
Myocardial infarction + Toremifene $(0.1 \mathrm{mg} / \mathrm{kg}),(\mathrm{n}=10)$ & $0.52 \pm 0.12^{*}$ & $1.1 \pm 0.1^{*}$ \\
Myocardial infarction + Thiotriazoline $(50 \mathrm{mg} / \mathrm{kg}),(\mathrm{n}=10)$ & $0.5 \pm 0.09^{*}$ & $0.9 \pm 0.08^{*}$ \\
Myocardial infarction + capicor $(6 \mathrm{mg} / \mathrm{kg}),(\mathrm{n}=10)$ & $0.68 \pm 0.11^{*}$ & $2.9 \pm 0.12^{*}$ \\
\hline
\end{tabular}

*: $p \leq 0.05$ in relation to the control.

Table 3. The impact of the studied drugs on the content of ST2 in the blood plasma and the percentage of survived animals on the $4^{\text {th }}$ day of experimental myocardial infarction

\begin{tabular}{lll}
\hline $\begin{array}{l}\text { Groups of animals } \\
(\mathrm{n}=10)\end{array}$ & $\begin{array}{l}\mathrm{ST2}, \\
\mathrm{mg} / \mathrm{ml}\end{array}$ & $\begin{array}{l}\text { \% of survived } \\
\text { animals }\end{array}$ \\
\hline Intact group, $(\mathrm{n}=10)$ & $11.4 \pm 1.59$ & 0 \\
Control group (myocardial infarction), $(\mathrm{n}=10)$ & $47.2 \pm 6.47$ & 40 \\
Myocardial infarction + Tamoxifene citrate $(0.1 \mathrm{mg} / \mathrm{kg})$ & $27.7 \pm 4.2^{*}$ & 70 \\
Myocardial infarction + Toremifene $(0.1 \mathrm{mg} / \mathrm{kg}),(\mathrm{n}=10)$ & $22.7 \pm 3.72$ & 80 \\
Myocardial infarction + Thiotriazoline $(50 \mathrm{mg} / \mathrm{kg}),(\mathrm{n}=10)$ & $36.8 \pm 4.12$ & 50 \\
Myocardial infarction + capicor $(6 \mathrm{mg} / \mathrm{kg}),(\mathrm{n}=10)$ & $32.2 \pm 3.41$ & 60 \\
\hline
\end{tabular}

*: $P \leq 0.05$ in relation to the control.

opinion, the realization of IL-33 cardioprotective properties. In addition, SERM can limit the development of oxidative and nitrosative stresses, leading to a decrease in the concentration of homocysteine and nitrotirozine in the heart. Interaction of these effects of tamoxifen citrate in conditions of acute cerebral ischemia led to a marked cardioprotective effect, increasing the percentage of survived animals to an average of $75 \%$.

\section{Conclusions}

1. Modelling of the acute myocardial infarction led to the significant pathobiochemical and electrophysiological changes in the heart tissue.

2. Experimental therapy of the rats with acute myocardial infarction with SERM and reference medications had cardioprotective effects, such as decrease of the oxidative and nitro-oxidative stresses markers, decrease of the serum ST2.

3. Effect of all medications in this study was unidirectional, but in the varying degrees. The most effective were Toremifen and Tamoxifen citritis, which decreased ST2 function more than $45 \%$, at the same time the percentage of survived animals was $45 \%$.

The cardioprotective effects of selective estrogen receptor modulators identified by us are an experimental foundation for the relevance and viability of further research in this direction.

\section{References}

[1] Kovalenko, V. M., Sirenko, Yu. M., \& Dorohoi, A. P. (2013) Khvoroby systemy krovoobihu u strukturi smertnosti naselennia Ukrainy: mify i realnist [Diseases of the circulatory system in the structure of mortality in Ukraine: myths and reality]. Proceedings of the XIV National Congress of Cardiologists of Ukraine. [in Ukrainian]

[2] Mokhort, M. A., \& Kutovyi, Yu. M. (2014) Prekondytsiiuvannia miokarda (ohliad literatury) [Myocardial preconditioning (literature review)]. Zhurnal NAMN Ukrainy, 20(2), 160-171. [in Ukrainian]. 
[3] Belenichev, I. F., Chernij, V. I., Pavlov, S. V., et al. (2015) Nejroprotekciya i nejroplastichnost' [Neuroprotection and neuroplasticity]. Kyiv: Logos [in Ukrainian].

[4] Belenichev, I. F., Odnokoz, O. V., Pavlov, S. V., Belenicheva, O. I., \& Polyakova, E. N. (2012) The Neuroprotective Activity of Tamoxifen and Tibolone during Glutathione Depletion in vitro. Neurochemical Journal, 6(3), 202-212. doi: 10.1134/s181971241203004X.

[5] Pavlov, S., \& Belenichev, I. (2014) Molecular and Biochemical Aspects of the Neuroprotective Effect of the Selective Estrogen Receptor Modulator Tamoxifen in a Model of Acute Cerebral Ischemia. Neurochemical Journal, 8(1), 28-32. doi: 10.1134/s1819712413040077.

[6] Pavlov, S. V., \& Levchenko, K. V. (2016) Vplyv estroheniv ta selektyvnykh moduliatoriv estrohenovykh retseptoriv na sertsevo-sudynnu systemu [Effect of estrogen and selective estrogen receptor modulators on the cardiovascular system]. Visnyk problem biolohii ta medytsyni, 3(2), 40-44 [in Ukrainian].

[7] Brann, D. W., Dhandapani, K., Wakade, C., Mahesh, V. B., \& Khan, M. M. (2007) Neurotrophic and neuroprotective effects of estrogen: Basic mechanisms and clinical implications. Steroids, 72(5), 381-405. doi: 10.1016/j.steroids.2007.02.003.

[8] Enmark, E., \& Gustafsson, J. A. (1999) Oestrogen receptors - an overvieu. J. Int. Med., 246(2), 133-8. doi: 10.1046/j.1365-2796.1999.00545.x.

[9] Kim, H. P. (1999) Non-genomic stimulation of estrogen receptors localised in caveolae. Biochem., Biophys. Res. Commun, 263 , 257-262.

[10] Pavlov, S. V., \& Levchenko, K. V. (2016) Antyoksydantni ta kardioprotektyvni vlastyvosti tamoksyfenu tsytratu za umov hipoksychnoho poshkodzhennia kardiomiotsytiv [Antioxidant and cardioprotective properties of the tamoxifen citrate in cardiomyocytes hypoxic damage] Farmakolohiia ta likarska toksykolohiia, 51(6), 66-72. [in Ukrainian]

[11] Mehta, S. H., Dhandapani, K. M., De Sevilla, L. M., Webb, R. C., Mahesh, V. B., \& Brann, D. W. (2003) Tamoxifen, a selective estrogen receptor modulator, reduces ischemic damage caused by middle cerebral artery occlusion in the ovariectomized female rat. Neuroendocrinology, 77, 44-50. doi: 68332.

[12] Barbarash, O., Gruzdeva, O., Uchasova, E., Dyleva, Y., Belik, E., Akbasheva, O. et al. (2016) Prognostic Value of Soluble ST2 During Hospitalization for ST-Segment Elevation Myocardial Infarction. Clinical Chemistry, 36, 313-319. doi: 10.3343/alm.2016.36.4.313.

[13] Willems, S., Sels, J. W., Flier, S., Versteeg, D., Buhre, W. F., de Kleijn, D. P. et al. (2013) Temporal changes of soluble ST2 after cardiovascular interventions. European Journal of Clinical Investigation, 43(2), 113-20. doi: $10.1111 /$ eci.12022.

[14] Skali, H., Gerwien, R., Meyer, T. E., Snider, J. V., Solomon, S. D., \& Stolen, C. M. (2016) Soluble ST2 and Risk of Arrhythmias, Heart Failure, or Death in Patients with Mildly Symptomatic Heart Failure: Results from MADIT-CRT. J. of Cardiovasc. Trans. Res, 9(5-6), 421-428. doi: 10.1007/s12265-016-9713-1.

[15] Hodakovskyi, O. A., Pavlov, S. V., \& Buhtiiarova, N. V. (2013) Vplyv ademolu na pokaznyky obminu NO v shchuriv iz modelliu infarktu miokarda [Ademol effect on NO exchange rates in rats with the model of myocardial infarction]. Ukrainskyi biokhimichnyi zhurnal, 85(3), 85-89. [in Ukrainian].

[16] Lapach, S. N., Chubenko, A. V., \& Babich, P. N. (2002) Statisticheskie metody $v$ mediko-biologicheskikh issledovaniyakh $s$ ispol'zovaniem EXCEL [Statistical methods in biomedical research using EXCEL]. Kyiv: MORION. [in Russian].

[17] Pavlov, S. V. (2011) Mitoprotektyvna diia tiolnykh antyoksydantiv v umovakh modeliuvannia nitrozuiuchoho stresu in vitro [Mytoprotective effect of thiol antioxidants in terms of modeling of nitrosating stress in vitro]. Zdobutky klinichnoi i eksperymentalnoi medytsyny, 2, 95-97. [in Ukrainian].

[18] Pavlov, S. V., \& Levchenko, K. V. (2016) Tsytoprotektyvni efekty skelektyvnykh moduliatoriv estrohenovykh retseptoriv za umov hipoksii kardiomiotsytiv in vitro [Cytoprotective effects of selective estrogen receptor modulators under hypoxia cardiomyocytes in vitro]. Farmakologiia ta likarska toksykologiia, 50(4-5), 78-83. [in Ukrainian]

[19] Pavlov, S. V., \& Bielenichev, I. F. (2013) Vmist stres bilka HSP70 i markeriv oksydatyvnoho stresu $v$ holovnomu mozku schuriv na riznyh terminakh tserebralnoii ishemii [The content of HSP70 stress protein and markers of oxidative stress in the brain of rats at different stages of cerebral ischemia]. Odeskyi medychnyi zhurnal, 3, 10-13. [in Ukrainian].

[20] Belenichev, I. F., Pavlov, S. V. \& Sokolik, E. P. (2011) Disturbance of HSP70 Chaperone Activity is a Possible Mechanism of Mitochondrial Dysfunction. Neurochemical Journal, 5(4), 251-256. doi: 10.1134/ S1819712411040040.

\section{Information about authors:}

Pavlov S. V., PhD, DSci (Biology), Associate Professor,

Head of the Department of Clinical Laboratory Diagnostics,

Zaporizhzhia State Medical University, Ukraine.

Levchenko K. V., Assistant, Department of Clinical Laboratory Diagnostics, Zaporizhzhia State Medical University, Ukraine. Gorbachova S. V., Associate Professor, Department of Clinical Laboratory Diagnostic, Zaporizhzhia State Medical University, Ukraine.

\section{Відомості про авторів:}

Павлов С. В., А-р біол. наук, Аоцент, зав. каф. клінічної мабораторної діагностики, Запорізький державний медичний університет, Україна.

^евченко К. В., асистент каф. киінічної лабораторної діагностики, Запорізький державний медичний університет, Україна. Горбачова С. В., Аоцент каф. клінічної лабораторної Аіагностики, Запорізький державний медичний університет, Україна.

\section{Сведения об авторах:}

Павлов С. В., А-р биол. наук, Аоцент, зав. каф. клинической лабораторной Аиагностики, Запорожский государственный медицинский университет, Украина.

левченко Е. В., ассистент каф. клинической лабораторной Аиагностики, Запорожский государственный меАицинский университет, Украина.

Горбачева С. В., Аоцент каф. клинической лабораторной Аиагностики, Запорожский государственный меАицинский университет, Украина.

Конфлікт інтересів: віАсутній.

Conflicts of Interest: authors have no conflict of interest to declare.

Надійшло Ао редакції / Received: 19.05.2017

Після Аоопрацювання / Revised: 04.07.2017

Прийнято Ао Аруку / Accepted: 18.07.2017 